\title{
Socio-Economic Factors Affecting the Perception of Women Entrepreneurs towards Bank Loan: A Study on Rajshahi City
}

\author{
Anima Karmakar*, Sadia Nur Habib, Atia Ahmed \\ Lecturer, Department of Business Administration, Varendra University, Rajshahi, BANGLADESH \\ *E-mail for correspondence: anima.karmakar67@gmail.com
}

https://doi.org/10.18034/abr.v8i3.161

\begin{abstract}
This study conducted to focus the women entrepreneurs' perception of how socio-economic factors influence at the time of taking a bank loan, whereas perception is the process by which an individual selects, organizes, and interprets stimuli into a meaningful and coherent picture of the world. The findings highlighted some socio-economic factors that influence women in taking a bank loan. Data collected from women entrepreneurs' residing in some major areas of the northern part of Bangladesh. A convenient sampling method was applied to collect response from 112 women entrepreneurs' of which 105 found free from errors; those respondents used for the final study.

Our study regarding the perception of the women reveals that religious view of our country, gender discrimination, and low educational qualification, lack of family support hinder their opportunity of taking a bank loan. Besides this research identify that advantageous living area \& high social status help women at the time of taking a bank loan. Furthermore, the findings have established that financial solvency, bank's rules \& regulations, mortgage criteria and the nature of business carry significant influences on women entrepreneur in taking loan. The foremost contribution of the current study is that it focuses women's observation and suggestion to break the barrier of getting the loan and find out a way to establish a positive attitude of the family as well as the society towards women entrepreneurs.
\end{abstract}

Key words: Socio-Economic Factor, Women Entrepreneurs, Perception, Bank Loan

\section{INTRODUCTION}

At the dawn of human civilization, women were the driving force of economic activities, but with passages of time due to changes of the social structure, they began to become engage in household activities rather than outside economic activities. But in modern time a nation cannot be developed unless it can ensure optimum utilization of all its available resources. So the time has come when we need to utilize the potential of female population for the development of a mainstream economy.

GDP is a good indicator of the economic stability of a country, where GDP indicates the gross domestic product that means the total quantity or amount of goods and services produced in a within a given period as well as within a year. To produce goods and services more production level must be increased. More production leads to more income and expenditure that show the higher standard of living. According to BBS, the total size of the GDP stood at Tk 19, 56,056 at the end of FY16-17. The growth rate of GDP in the fiscal year 2016-2017 is 7.247\%. The size of the population is 15.89 crore at the end of FY1617. The ratio of male-female population is 100.3:100.The no. of people able to work (15+) is 6.1 crore. The number of male-female worker is respectively 4.3 crore and 1.8 crores.

In the financial year 2017-2018 the GDP, size is $\$ 274.5$ billion in dollar term. The country's per capita income is $\$ 1,752$, in FY 2017-18. GDP growth rate in FY 2017-18 is likely to be 7.65 percent. The size of the population is $166,368,149$ at the end of FY17-18 among which $50.41 \%$ of total population is Male, and $49.59 \%$ constitutes Female. It clearly shows that near about $50 \%$ of the population is female. So to increase GDP or living standard as well as to ensure a self-reliant economy, women entrepreneurs must be encouraged.

Starting a business capital plays the most significant role, and considers as the heart of business. Traditionally it can be managed in two ways. Firstly, it may arrange by investing owner's capital and the second way is through borrowing fund. As a developing country, the people of 
Bangladesh usually don't have enough resources of their own to invest in their business. Capital market and financial institutions provide the borrowing fund to deficit unit who needs funds to start a new business or run their existing business smoothly.

Entrepreneurs prefer to take the loan from financial institutions to finance their business especially banks; as banks are prominent financial institutions in Bangladesh for providing loans. Though in taking the loan from a bank there are different requirements that must be met by the entrepreneurs, but women entrepreneurs not only face the banking legislative difficulties but a variety of social factors also work as the constraint in taking the bank loan. Woman entrepreneur when try to get a bank loan different social issues such as face religion, ethnicity, education, locality, social perception towards business, age, family time, motherhood, socio-legal factors and so on confine their way.

\section{ObJectives OF The Study}

The overall objective of the study is to represent the key issue involved in taking the bank loan of women entrepreneur. Therefore, the principal objectives of the study are:

- To identify the factors those have positive influences on women's perception towards bank loan.

- To examine the factors those obstruct women in taking bank loan.

\section{LITERATURE REVIEW}

Entrepreneur indicates a person who is dynamic, innovative, risk seeker, creative and acting as an economic agent concerned with the production and distribution of services. "The word entrepreneur has taken from the French verb enterprenerd that means to undertake."

By Wikipedia ${ }^{1}$, the history of female entrepreneur began before the 20th century where female operated small businesses as a way of supplementing their income. In many cases, they were trying to avoid poverty or were replacing the income from the loss of a spouse. At that time, the ventures that these women undertook were not thought of as entrepreneurial. Many of them had to focus on their domestic responsibilities. The term entrepreneur is used to describe individuals who have ideas for products or services that they turn into a working business. In earlier times, this term was reserved for men.

In the 17th century, Women became more involved in the business world and in the time of 18th and 19th centuries more women came out from under the oppression of society's limits, and began to emerge into the public eye.

During WWII, many women entered the workforce, filling jobs that men had left behind to serve in the military. Some women, of their own accord, took these jobs as a patriotic duty while others started businesses of their own. The 1980s and 1990s were a time of reaping the benefits from the hard work of women who worked tirelessly for their rightful place in the workforce as employees and entrepreneurs.

As the 1990s came in, the availability of computers and the increasing popularity of the internet gave a much-needed boost to women in business. This technology allowed them to be more prevalent in the business world and showcase their skills to their competitors. Since 2000, there has been an increase in small and large ventures by women, including one of their biggest obstaclesfinancing. Even though women entrepreneurship and therefore the formation of women-owned business networks are steady rising, there are a variety of challenges and obstacles that women entrepreneurs face.

A research conducted in Mashonaland Central Province of Zimbabwe reveals that women entrepreneurs face constraints related to access to finance, conflicts between work and family responsibilities, networking challenges, lack of education and management skills (Mauchi et al., 2014). A Case Study Analysis of Rangpur, Bangladesh from empowerment Perspective adjust somewhat to the Marxist view-point of women's direction, where Marxists view focus that men are from a privileged class, while women constitute an under privileged, exploited and oppressed class (Rahman and Reza, 2016).

Bangladeshi women micro-entrepreneurs face an unfavorable business environment that is characterized by various challenges ranging from low technical, administrative and government support, lack of scope of professional development and bad interpersonal relationship (Nasima and Alam, 2014). The findings also highlight the socio-economic characteristics such as age, marital status; educational status and starting age of business also play a significant role. The foremost barriers encountered by women entrepreneurs are finance, administrative and regulatory requirements, lack of management skills or training, lack of confidence, lack of working capital, male-dominated society and different kinds of socio-cultural barrier (Bharthvajan, 2014). Women entrepreneurs challenges are inadequate capital, sales promotion, getting permission to start-up a business, gender discrimination, illiteracy and lack of knowledge among women, non-availability of training program and technical support, lack of managerial experience, in some cases young people make ill talk about the enterprise and so on (Afroze et al., 2014). Women entrepreneurs face weird challenges in an attempt to achieve success (Hatcher et al., 2007) and women in less developed countries face much more barriers to formal economic participation than those in developed countries (Allen et al., 2008).

Business environment factors such as credit accessibility exert much more influence on the entrepreneurial activity of women entrepreneurs than individual attributes like education, experience, and risk-taking attitude (Ekpe et al., 2011). Seeking balance in work-family has been established as a significant factor in women's decision to 
start a business (Chaganti, 1986; Holmquist and Sundin, 1988), although women business owners still appear to experience much greater conflict than men in managing family and work life (Parasuraman et. al., 1996).

Unequal access to education restricts women from acquiring even functional levels of literacy required to learn skills. Regarding skill development, women are impeded by their lack of mobility, low literacy levels and prejudiced attitudes towards women (Kumari et.al, 2010).

Cesaroni and Sentuti (2016) identified that female entrepreneurs start their firms with a lower level of funding than male entrepreneurs (Alsos, et al., 2006), are less likely to raise capital from external sources (Constantinidis and Cornet, 2006; Fairlie \& Robb, 2009; Robb \& Walken, 2002), even in the subsequent phases of their entrepreneurial life cycle, and are more likely than men to use personal loans - from family and friends (Coleman \& Robb, 2009).

A primary and continuing obstacle faced by women appears to be difficulty in securing capital funding for new business ventures (Buttner and Rosen, 1992; Canadian Federation, 1995; NFWBO, 1992). Riding and Swift (1990) concluded financial conditions for women business owners were less favorable than for men: women more often had to pay higher interest rates, find more collateral, and provide a spouse's co-signature.

\section{Methodology}

\section{Population and Sample}

The population comprised of women entrepreneurs based in Rajshahi city and its adjacent area of northern part of Bangladesh. Random sampling was done, and from the population through convenient sampling 112 women entrepreneurs were chosen. Among the responses, seven got rejected as these were not accurately filled-up. The rest of the 105 responses have taken for analysis.

\section{Data Collection}

For data collection purpose a face to face interview was conducted. Respondents were questioned about the factors they face in getting a bank loan. The time duration of the field review was April 2018 to June 2018.

\section{Data Analysis and Results}

For satisfying the objectives of this research, descriptive research has been performed. A questionnaire developed containing 20 questions related to social problems, family problem and other problem faced by women entrepreneur. The likert scale used for the attainment of the result.

Data collected were tabulated and analyzed using MS Excel graphs and SPSS software.

After the data was classified, it was then presented and analyzed in the form of tables, graphs, charts, and frequencies. Having drawn the graphs, charts, and tables further analysis was done, which encompassed describing, interpreting, Cross -referencing and comparing variables. Conclusions drawn from the results were generalized to cater for the whole population.

\section{FINDINGS AND ANALYSIS}

\section{Demographic Segmentation}

In our demographic segmentation, we only focus our respondent's age, education qualification, and nature of the business they have conducted.

\begin{tabular}{|c|l|c|c|}
\hline Variable & \multicolumn{1}{|c|}{ Class } & Frequency & Percentages \\
\hline Age & $21-25$ & 12 & $11.43 \%$ \\
& $26-30$ & 25 & $23.81 \%$ \\
& $31-35$ & 27 & $25.71 \%$ \\
& $36-40$ & 14 & $13.33 \%$ \\
& $41-45$ & 19 & $18.09 \%$ \\
& Above 45 & 8 & $7.62 \%$ \\
\hline Educational & Below SSC & 20 & $19.05 \%$ \\
qualification & SSC & 32 & $30.47 \%$ \\
& HSC & 28 & $26.67 \%$ \\
& Graduate & 17 & $16.19 \%$ \\
Nature of & Post Graduate & 8 & $7.62 \%$ \\
\cline { 2 - 4 } business & Partique House \& Cloth Business & 45 & $42.85 \%$ \\
& Grocery \& Stationary Handicrafts & 20 & $19.04 \%$ \\
& Agro Based Business & 7 & $11.42 \%$ \\
\cline { 2 - 4 } & Livestock's & 6 & $6.67 \%$ \\
& Others & 15 & $14.71 \%$ \\
& & \multicolumn{2}{|c}{} \\
\hline
\end{tabular}

\section{Perception Analysis of Women Entrepreneurs}

\section{Perception about the religious view}

From an Islamic point of view, there are devout Muslims who refuse to deal in interest because interest has forbidden in Islam. In modern times, all the business activities running with the help of financial institutions as taking a loan to collect fund but many of them believe that the bank loan is not halal because the core function of the banks depends on interest. In our study maximum number of respondents either strongly agrees $(61 \%)$ or agrees $(11 \%)$ with the statement that religious view toward bank loan creates problem to get the bank loan. The table or analysis shows that only $9 \%$ of respondents strongly disagree with this statement. The mean value (4.06) strongly supported that women's' perception toward bank loan is hindered by the religious view.

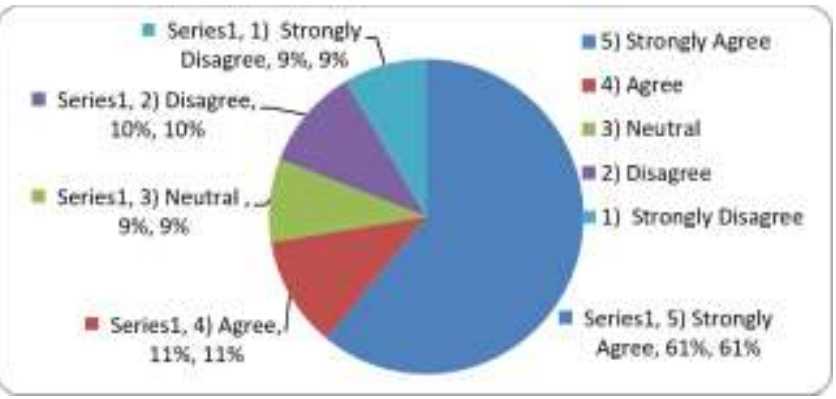

Figure 1: Women Entrepreneurs' perception about the religious view 


\section{Perception about gender favoritism/discrimination}

As male-dominated society women face different kinds of challenges in their workplace like lack of confidence, lack of respect, sexual harassments, etc. the mean value 3.15 indicates that respondents' women entrepreneurs are suffering from receiving more confident attitude from the bank in getting a loan. Although $42 \%$ of respondent disagreed with this statement, but the standard deviation (1.58) shows that the observations are close to mean and reliable.

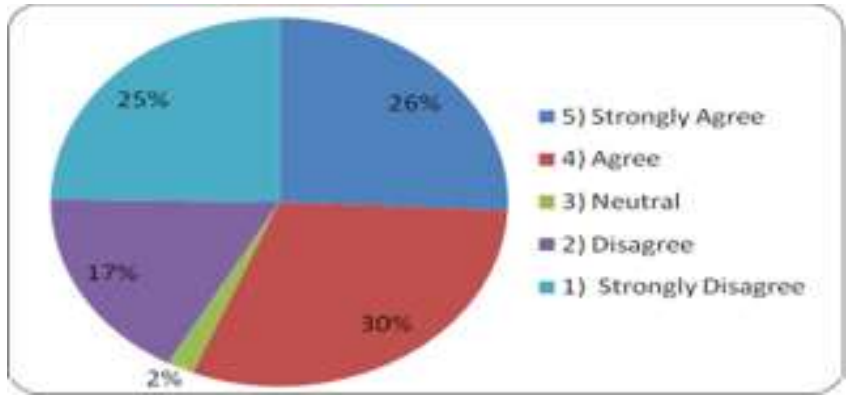

Figure 2: Respondents' perception about gender favoritism/discrimination

\section{Perception about educational qualification}

Women perception towards how bank considers educational qualification of an entrepreneur in case of approving loan proposal-

Education plays a vital in the expansion of national income by rising the productive capacities of the labor pool. To increases the rate of labor force skilled people is the must

Our study figured out that more than 50\% -it segmented as $30 \%$ strongly agreed, and another $30 \%$ of respondents agreed with this statement. The mean value suggests that in the time of loan proposal the bank emphasis on loanee's educational qualification. The standard deviation is quite supportive regarding this statement although $31 \%$ of respondents disagree with this statement.

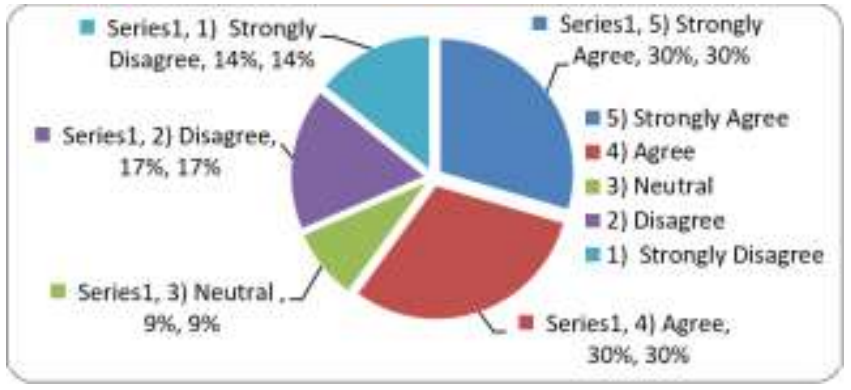

Figure 3: Respondents perception about bank's point of view regarding educational qualification of entrepreneur while approving loan

Women perception towards the statement "getting a bank loan is easier for those women who are independent in decision making."
In our study among 105 respondent, 61\% respondent's perception is similar with our statement that indicates a self-determining decision maker women face less hazard to take the bank loan. The standard deviation (1.60) shows that the observations are close to mean and trustworthy.

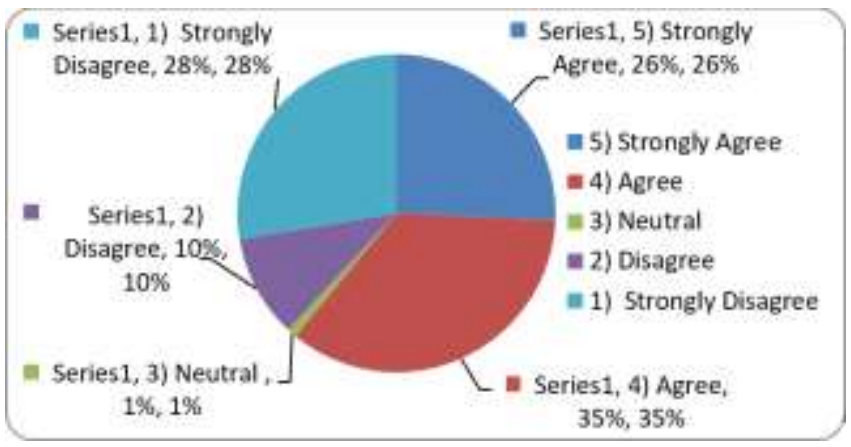

Figure 4: Women responses towards the statement "getting a bank loan is easier for those women who are independent in decision making."

Perception about living place/ area/ region/ status/ regional status

Usually, the rural women are deprived of many facilities compare with urban women. But according to our respondents, living in the rural area does not seem to have much effect in case of getting the bank loan. When they are being asked their perception about whether rural women face more complexity in getting the loan than civic/urban women, only $10 \%$ of our respondents strongly disagree with this perception while $70 \%$ of respondents strongly agree and agree with this perception.

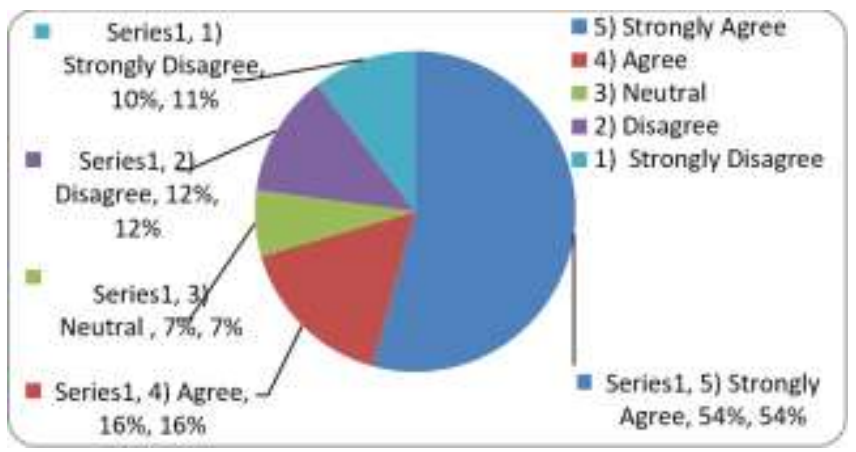

Figure 5: Respondent's perception about living place/ area/region/status/regional status

\section{Perception about social attitude}

Women's perceptions whether society has a positive attitude towards their business

In our study, most of the respondents indicate that people has a positive attitude toward their business, but $15 \%$ and $9 \%$ respectively disagree and strongly disagree with this statement. But $73 \%$ of respondent supported with this statement and the mean value (3.88) indicates that in modern time society has a positive attitude toward 
women for business and the standard deviation (1.39) prove that our observations are not too much scattered from the mean.

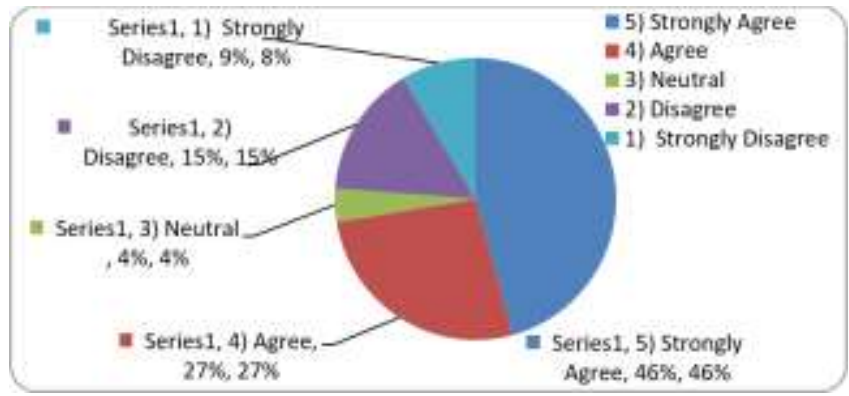

Figure 6: Women's perceptions about the society's positive attitude towards their business

Women's perceptions of whether society's attitudes toward business discourage them from taking risks

Our previous study reveals that women think that people has a positive attitude toward women entrepreneur so in this sense it's normal to assume that women are encouraged from society in the term of taking the risk. The mean value (2.59) indicate an indifferent situation regarding this issue where $24 \%$ \& $38 \%$ respondent disagree and strongly disagree with that statement that said society's negative attitude toward business discourage women from taking risks.

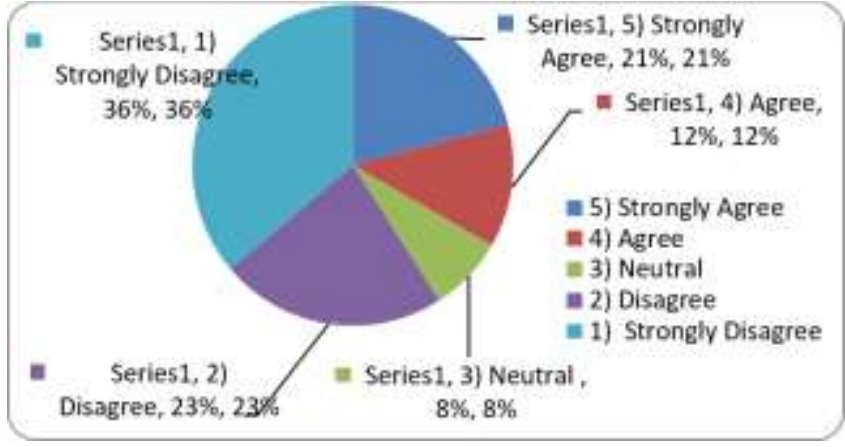

Figure 7: Women's perceptions of whether society's attitudes toward business discourage them from taking risks

\section{Perception about family support}

Women's perception about whether family encourages/supports them to take a loan from the bank

In Bangladesh family have an unavoidable impact on women's business. It plays a very significant part not only as a source of restraint, obligations, and duties, but also as a source of funds and support. It is important to focus on the family's role in women's business. From this point of view, respondents were asked about their perception towards family support. The mean value (2.50) from the conducted study suggests that family discourages women in taking the bank loan and standard deviation indicates that the observations are close to mean. In our study, only 7 percent of our respondents strongly agree that their family encourages them to take the bank loan.

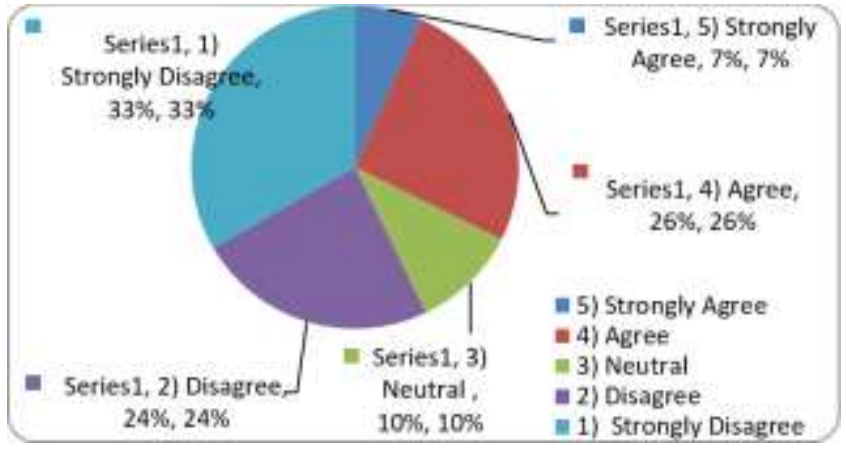

Figure 8: Women's perception toward family supports in taking the bank loan

Women perception towards the statement "A busy entrepreneur will give less time to her family," this view creates more complexity for a woman in getting a loan."

Since women entrepreneurs have to assume multiple roles in the family in addition to their careers, their responsibilities give rise to work-family conflict. Sometimes these conflicts become a hindrance in performing their responsibility towards the family. In this context, there may have been a possibility that the family will not support women not only in opening or developing a business but also in getting a bank loan. But the study depicts that more than half of the respondents (57 out of 105) responded negatively to the statement. "A busy entrepreneur will give less time to her family," this view creates more complexity for a woman in getting the loan." Likewise the mean value (2.91), not as much of supports this.

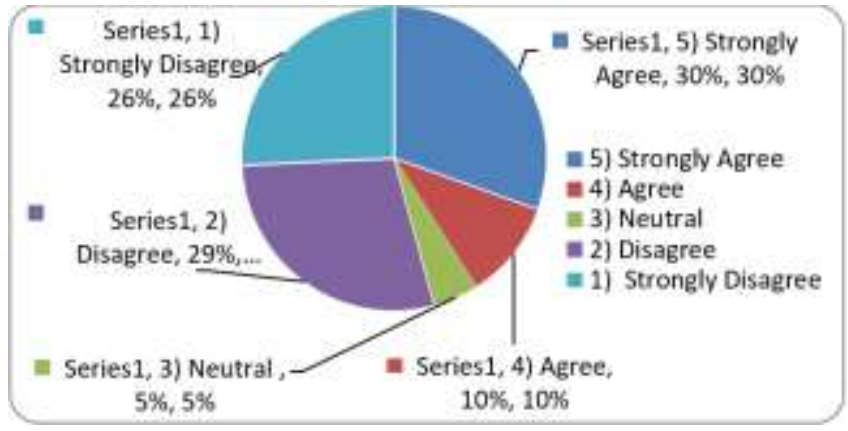

Figure 9: Women perception towards the statement "A busy entrepreneur will give less time to her family," this view creates more complexity for a woman in getting a loan

Women's perception whether a female member of a joint family gets more support in case of taking bank loan than a member of a nuclear family

Joint families have been in the Bangladeshi culture for a very long time. Though with the passage of time this system has been losing its recognition and the popularity of nuclear family is growing, the appeal of the joint family still exists. To examine the support given by the family, respondents were asked about their perception regarding these two family structures. 
The result shows that $34 \%$ of the respondents strongly agreed and $25 \%$ of them agreed to the statement "a female member of a joint family gets more support in case of taking bank loan than a member of a nuclear family." The mean value (3.45) also suggests that the member of joint family encourage more to take bank loan than a nuclear family. The standard deviation (1.474) reasonably supportive regarding this statement although $44 \%$ of respondents hold opposing views with this statement.

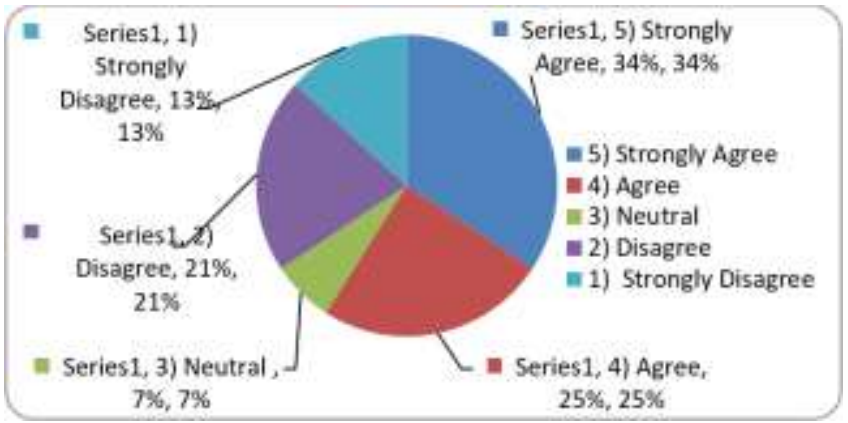

Figure10: Women's perception whether a female member of a joint family gets more support in case of taking bank loan than a member of a nuclear family

\section{Perception about social status}

Perception whether the family status of a loanee plays a vital role in getting the loan

To evaluate a borrower's ability to pay the loan, bank emphasis on family status or social position of the borrower. Any individual or business needing funds for an activity is, in the process of a usual financial transaction, entirely evaluated before a loan is approved. Providing credit approval by a creditor can be a bank, a business or other financial institutions) therefore depends on the ability and willingness of the borrower to return the money or pay for the goods obtained-plus interest-in a timely fashion. The key criteria used by a formal financial institution to grant loans constitute the establishment of a borrower's creditworthiness. Creditworthiness, which encompasses the borrower's ability and willingness to pay, is one of many factors defining credit policies. Creditors and lenders utilize some financial tools to evaluate the creditworthiness of a potential borrower. More than 70 percent of respondents agree \& strongly agree with this statement.

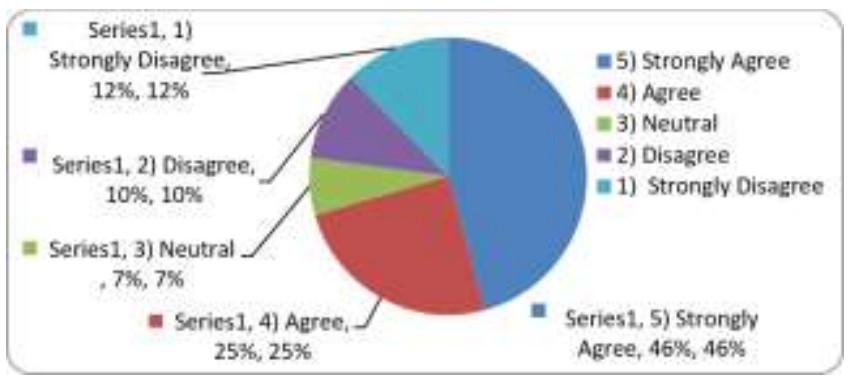

Figure 11: Perception whether the family status of a loanee plays a vital role in getting the loan
The mean value (3.81) suggests that family status of a loanee plays a vital role in getting the loan and the standard deviation of the data indicates that the value is located close to the mean. From our observation, only $12 \%$ of respondent strongly disagree with this statement.

Perception whether an unmarried woman face more difficulties in case of getting the loan than a married woman

Marital status is the challenge that women entrepreneur face in term of taking a loan from bank. Bank official tend to prefer speaking to their husband instead of the women entrepreneur. Our study figured out that more than half of the respondents respond positively to the statement. The mean value has the strong tendency to support the respondent perception that unmarried women face more difficulties in case of getting the loan than a married woman and the low variance of the information indicates that the worth is found on the point of the mean.

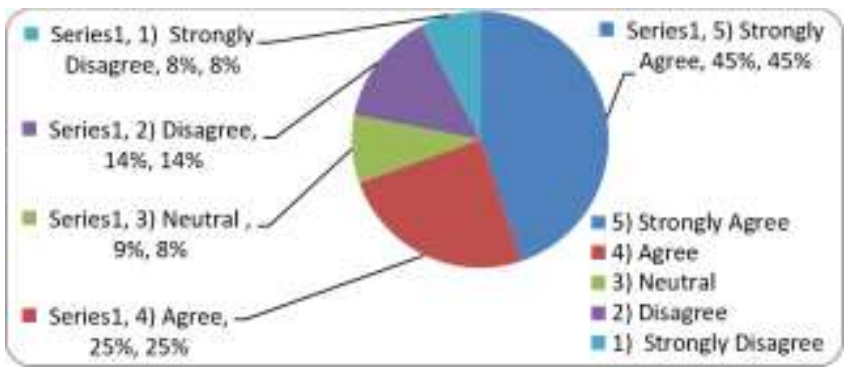

Figure 12: Perception whether an unmarried woman faces more difficulties in case of getting the loan than a married woman

\section{Perception about financial solvency}

Whether insufficient mortgage giving capacity creates a barrier in getting the bank loan

A mortgage is a way to use one's real property, like land, a house, or a building, as a guarantee for a loan to get money. Our study reveals that our $70 \%$ \& $22 \%$ respondent strongly agree and agree respectively with the issue that insufficient mortgage giving capacity creates a barrier in getting the bank loan. This statement has boldly supported by the mean value (4.57), and the standard deviation (0.807) indicates that the observations are not widely scattered about the mean.

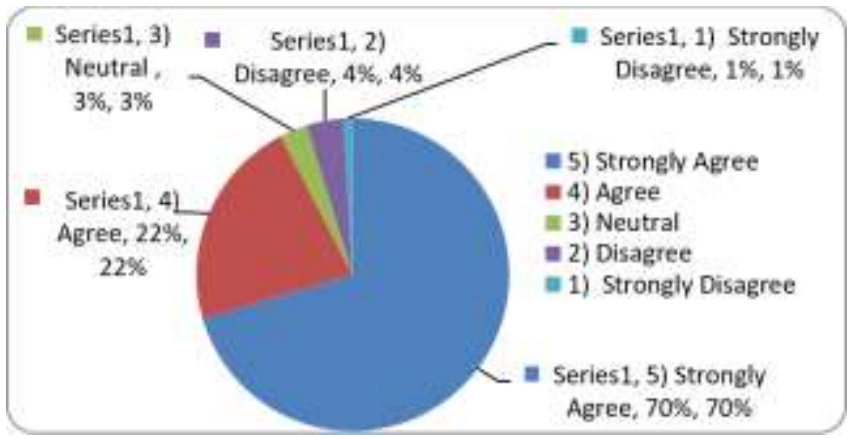

Figure 13: Whether insufficient mortgage giving capacity creates a barrier in getting the bank loan 
Whether getting the bank loan is easier to the women who are financially independent

In general, the granting of a loan depends on the confidence the lender has in the borrower's creditworthiness. Creditworthiness encompasses the borrower's ability and willingness to pay. Financial independency is a key factor that affects the borrower's ability to pay.

According to Wikipedia ${ }^{2}$, Financially independent people have assets that generate income (cash flow) that is at least equal to their expenses.

In our study, $75 \%$ respondent boldly supported women's financial independency to get the bank loan in easily. A mean value (3.76) and standard deviation (1.458) support their perception although $25 \%$ of our respondents oppose with this statement.

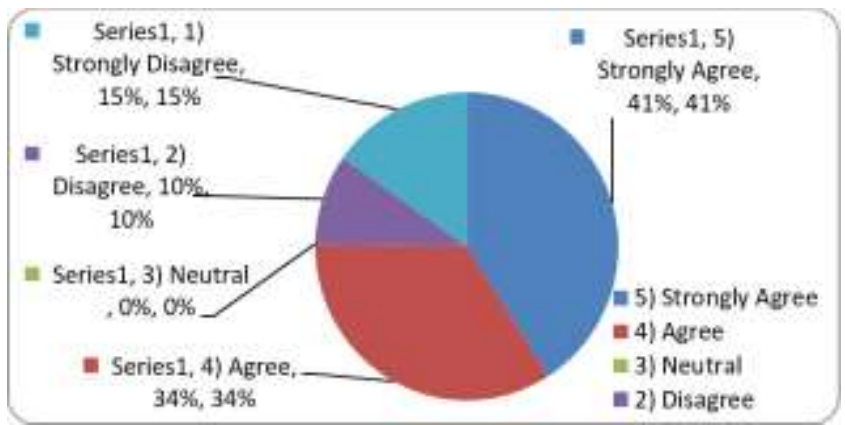

Figure 14: Whether getting the bank loan is easier to the women who are financially independent

\section{Perception about the approach of the bank}

Whether banks show less interest/faith in young women entrepreneur and their loan proposal

Young women entrepreneurs have less knowledge and experiences about business. So the bank tends to analyze more and more to grant or accept loan proposal from a new or early aged women. Regarding this statement, our $38 \%$ respondents strongly agree, and $27 \%$ agree about the perception of the bank toward young women.

A mean value (3.67) and standard deviation (1.356) support their perception whereas only $6 \%$ of our respondents strongly disagree with this statement.

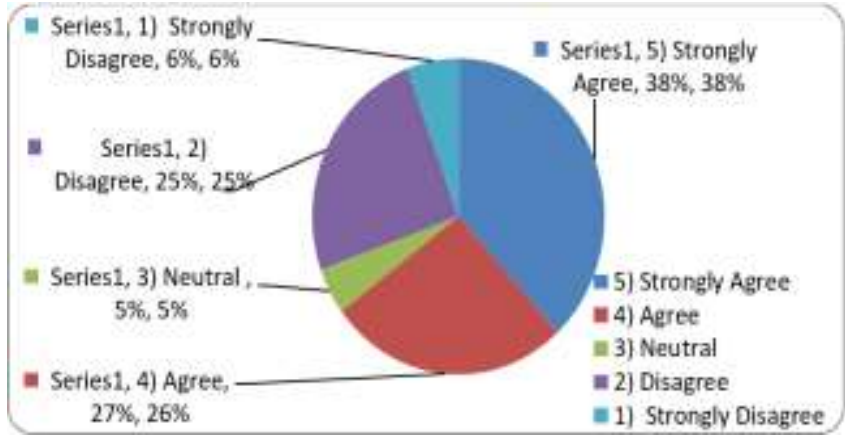

Figure 15: Whether banks show less interest/faith in young women entrepreneur and their loan proposal
Whether a married woman face more difficulties in case of getting the loan than an unmarried woman

Though the bank has a positive attitude toward married women to provide a loan, but in our study respondent express a vice versa scenario to get a bank loan. Because of different types of household work and many other inlaws responsibilities make an obstacle expanding their business as well as to get a loan. The mean value of our study indicates that most of our respondents think that married woman face more difficulties in case of getting a loan than an unmarried woman.

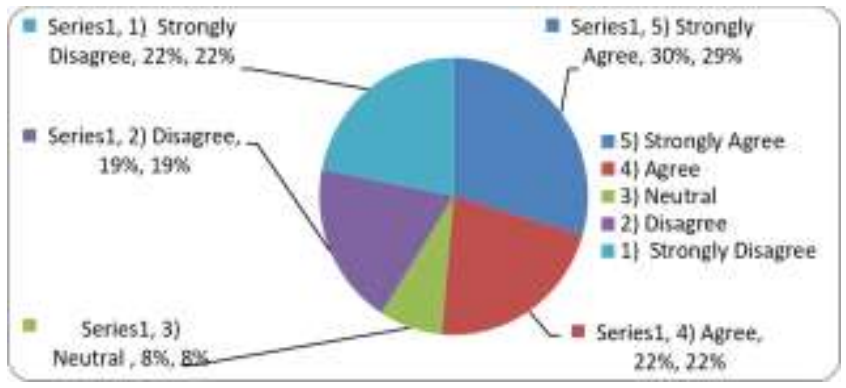

Figure 16: Whether a married woman face more difficulties in case of getting the loan than an unmarried woman

Whether child raising responsibility of women create problems in her business and her capability to take the loan

For a woman, child raising responsibilities is a noble task in their perception. So 50 percent of our respondent opposed this issue where rests of respondent have the same opinion with this statement.

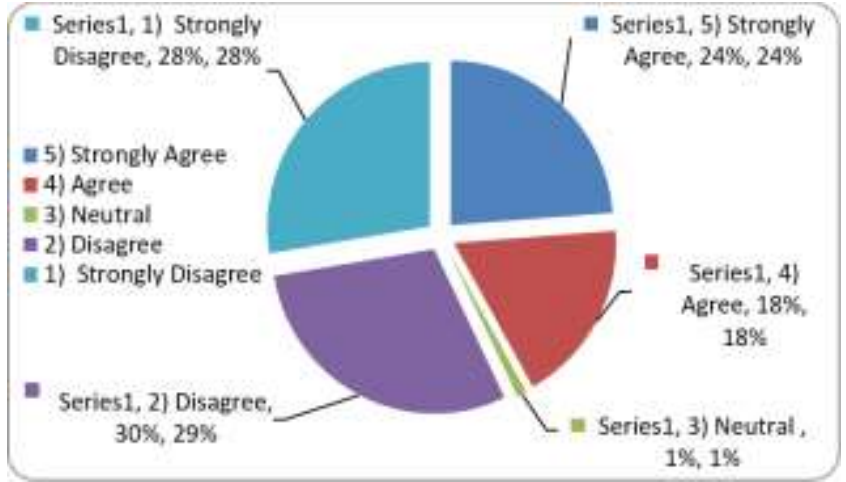

Figure 17: Whether child raising responsibility of women create problems in her business and her capability to take the loan

\section{Perception about bank policy}

Whether the rules and regulations imposed by the bank create hindrances in getting the loan

Most of the women in Bangladesh feel that strict rules and regulation adopted by the bank is the main hindrance they are facing in fulfilling their dreams to be an entrepreneur. From our observation, in our study, $18 \%$ of respondent 
agree and 58\% respondent strongly agree that more rules create more complexity to the take bank loan. A mean value of 3.98 strongly supported their perception. Although 22\% respondent opposed this statement but the standard deviation (1.487) proves that our observations are not too much spread about the mean.

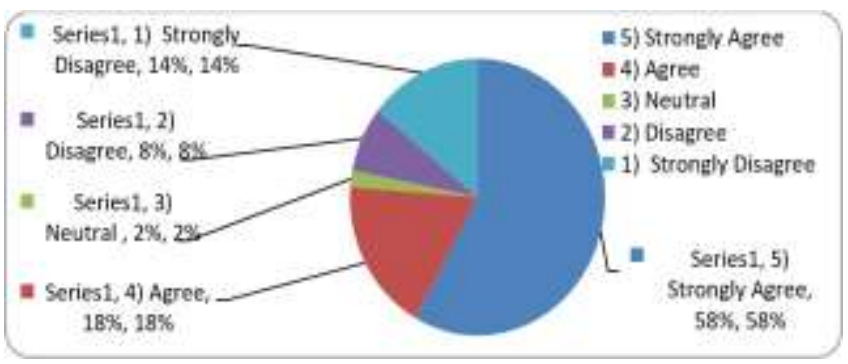

Figure 18: Whether the rules and regulations imposed by the bank create hindrances in getting the loan

\section{Whether guarantor's profile plays a vital role for women entrepreneur in case of getting a loan}

A guarantor ensures that if the borrower cannot make loan repayments, the guarantor will pay them. Since the guarantor has a financial obligation to make the monthly repayments if the borrower defaults it is essential that guarantor should have a good credit history with financial stability. In our country, guarantor's social recognition and good relation with lending bank also play a crucial role.

In this scenario, our women think that guarantor having an impressive profile with financial stability and social acknowledgments help them in getting bank loan.

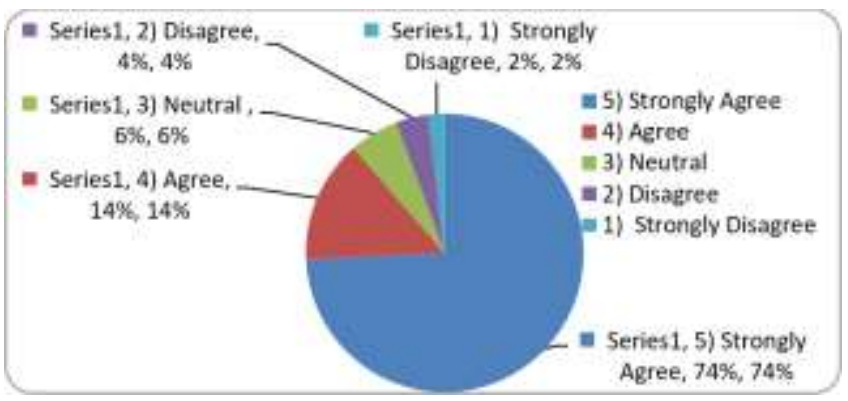

Figure 19: Whether guarantor's profile plays a vital role for women entrepreneur in case of getting a loan

\section{Whether the nature of business plays a vital role in getting the bank loan}

Like all other commercial institutions, banks are run for profit. Even government-owned 'banks are no exception to this. Before giving financial credit, banks consider the source from which repayment is promised.

Obviously, they look for businesses that show promise and they award loans to those businesses which are more profitable from their viewpoint. Beside banks will also consider the current economic conditions, industry trends and even the direction of politics.
Majority of our respondents also feel that the nature of businesses which seem to have a more favorable position and potentiality under these circumstances get priority in getting a loan.

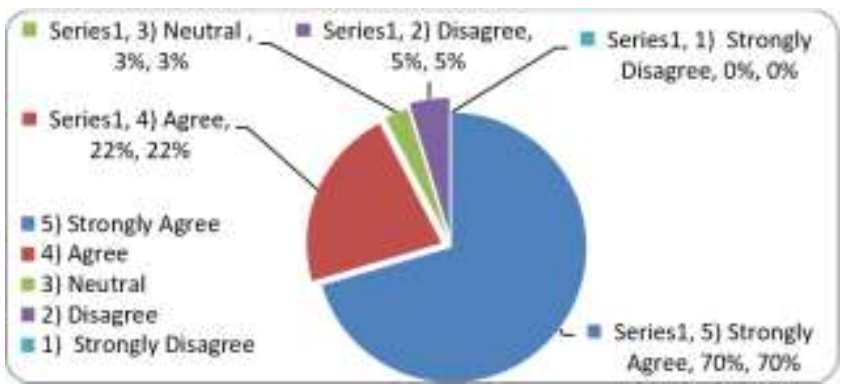

Figure 20: Whether the nature of business plays a vital role in getting the bank loan

\section{CONCLUSION}

Living in a male-dominated economy it is eye-catching that major portion of registered small and medium-size enterprises (SMEs) in emerging markets area unit closelyheld by women and they have an enormous contribution in manufacturing, selling, and providing much-needed goods and services, creating jobs, and boosting local and national economies. But it is also true that Women experience barricades in almost every phase of work. We must enhance different types of support that might be most helpful for them in addressing the issues and problems that they are facing. Special scheme should be implemented whereby women can get bank loans without facing any harassment, such as equal and better educational facilities should be provided to the women, change the attitude of society towards women by building mass awareness, whereas all reasonable media such as TV, Newspaper, Radio, the Internet will play a significant role.

Moreover financial institutions like banks, NGOs should introduce various types of women-friendly lending opportunities without or minimum mortgage requirement \& these institutions ought to flexible their rules, regulations and policies in case of providing a loan to women entrepreneur.

Counseling \& recommendation facilities, Training center, Technology learning center can also be set up just for women so economical and independent women force are often created. Last, of all family and society need to realize that when they support women entrepreneur in establishing her own business, it helps to create more employment opportunities, better living standard, increased economic growth to her family as well as to the society and more likely to the country.

This study has some limitations as long as we tend to analyze just some major areas of northern part of Bangladesh and moreover, the number of entrepreneurs is limited and does not allow us to obtain generalizable 
results. Further analysis ought to examine a bigger sample involving a wider geographical area and completely different legal forms. It additionally would be attentiongrabbing to expand this analysis to alternative countries, in a very Comparative fashion, so as to raise determine women Entrepreneurs perceptions towards bank loan and help the concerning body to develop the necessary policy to revive the women entrepreneurs.

\section{REFERENCES}

Adema, W., Ali, N., Frey, V., Kim, H., Lunati, M., Piacentini, M., \& Queisser, M. (2014). “Enhancing Women's Economic Empowerment through Entrepreneurship and Business Leadership in OECD Countries" Background Report to China Development Research Foundation Project Enhancing Women's Economic Empowerment through Entrepreneurship and Leadership In The Midst Of China's Urbanization

Afroze, T., Alam, M. K., Akther, E., \& Jui, N. S. (2014), Women Entrepreneurs in Bangladesh-Challenges and Determining Factors, Journal of Business and Technology (Dhaka), VolumeIX, Issue-02, July-December, 2014

Ali, M. M. (2015). Borrowers' Perception: SMBEs Financing by the Banking Sector of Bangladesh. Daffodil International University Journal of Business and Economics,. Vol. 9,. PP. 53-76.

Allen, I. E., Elam, A., Langowitz, N. \& Dean, M. (2008). 2007 Global Entrepreneurship Monitor report on women and entrepreneurship. Babson College: The Centre for Women's Leadership.

Alsos, G. A., Isaksen, E. J., \& Ljunggren, E. (2006). New venture financing and subsequent business growth in men- and women-led businesses. Entrepreneurship Theory and Practice, 30, 667-686. doi:10.1111/j.1540-6520.2006.00141.x.

Bangladesh Statistics (2017). Bangladesh Bureau of Statistics (BBS) Statistics and Informatics Division (SID), Ministry of Planning, Bangladesh (http:/ /bbs.portal.gov.bd/)

Bharthvajan R (2014). "Women Entrepreneurs \& Problems of Women Entrepreneurs". International Journal of Innovative Research in Science, Engineering and Technology, Vol. 3, Issue 9, September 2014,pp.3(9), 1-7.

Buttner, E.H., \& Rosen, B. (1992). "Entrepreneurs reactions to loan rejections". Journal of Small Business Management, 30(1): 59-66

Byron, R. K. (2018) Economy marches towards record 7.65pc growth, The Daily Star, April 04 (https:/ / www.thedailystar.net/)

Cesaroni, F. M., \& Sentuti, A. (2016), Economic crisis, women entrepreneurs and bank loans: some empirical evidence from Italy, Economic Research-Ekonomska Istraživanja, 2016 Vol. 29, No. 1, 1050-1061 http:/ /dx.doi.org/10.1080/1331677X.2016.1211953

CFIB (1995). Canadian Federation of Independent Business, Small business and equal employment opportunities: A review of women business owners in Canada. Toronto, ON: Canadian Federation of Independent Business.

Chaganti, R. (1986). "Management in women-owned enterprises". Journal of Small Business Management, 24(4): 1829.
Coleman, S., \& Robb, A. (2009). A comparison of new firm financing by gender: evidence form the Kauffman Firm Survey Data. Small Business Economics, 33, 397-411. doi:10.1007/s11187-009- 9205-7.

Constantinidis C., and Cornet A. (2006), "Financing of womenowned ventures: the impact of gender and other owner- and firm-related variables", Working Paper, Ecole de Gestion de l'Université de Liège.

Ekpe, I., Mat, N., \& Razak, R. C. (2011). Attributes, Environment Factors and Women Entrepreneurial Activity: A Literature Review, Asian Social Science, Vol. 7, No. 9, p.127

Fairlie, R. W., \& Robb, A. (2009). Gender differences in business performance: Evidence from the Characteristics of Business Owners' survey. Small Business Economics, 33, 375-395. doi:10.1007/ s11187-009-9207-5.

Hatcher, C., Terjesen, S. \& Planck, M. (2007). "Towards a new theory of entrepreneurship in culture and gender:A grounded study of Thailand's most successful female entrepreneurs". Australia: AGSE.

Holmquist, C. \& Sundin, E. (1990). “What's special about highlyeducated women business owners?" Entrepreneurship and Regional Development, 2: 181-193.

Kumari, S., Kaushik, V., \& Lodha, N. (2010). Problems Faced by Rural Women Entrepreneurs of Rajasthan, Stud Home Comm Sci, 4(2): 115-119 (2010), p.115

Mauchi, F. N., Mutengezanwa, M., \& Damiyano, D. (2014). "Challenges faced by women entrepreneurs: A case study of Mashonaland Central Province". International Journal of Development and Sustainability, 3(3), 466-480.

Mwobobia, F. M. (2013). “The Role of Banks in Empowering Women Entrepreneurs in Small and Micro Enterprises (SMEs) in Kenya: A Case of Cooperative Bank of Kenya". International Journal of Business Administration Vol. 4, No. 3; 2013.

Nasima, M. and Alam, N. (2014). Women Micro-Entrepreneurs in Bangladesh: Socio-Economic Aspects and Factors Affecting Their Development, Journal of Business 54 and Technology (Dhaka), Volume-IX, Issue-01,

NFWBO (1992) National Foundation for Women Business Owners. Women owned businesses: The new economic force. Washington, DC.

Omonywa, T. N., \& Muturi, W. M. (2015). Factors Affecting Loan Repayment by Women Entrepreneurs: A Case of Kisii Country, Kenya, International Journal of Economics, Commerce and Management United Kingdom Vol. III, Issue 4, April 2015

Parasuraman, S., Purohit, Y., \& Godshalk, V.M. (1996). “Work and family variables, entrepreneurial career success and psychological well-being". Journal of Vocational Behavior, 48(3): 275-300.

Parvin, L., Jinrong, J., \& Rahman, M. W. (2012). “Women entrepreneurship development in Bangladesh: What are the challenges ahead?". African Journal of Business Management, 6(11), 3862-387

Pelger, I., \& Tchouvakhina, M. (2013). "Low debt entrepreneurs: in financing matters, women entrepreneurs play it safe". KFW Economic Research, 1-3. 
Rahman, M. \& Reza, R. (2016). Women Entrepreneurs: A Case Study Analysis of Rangpur, Bangladesh from Empowerment Perspective, IOSR Journal Of Humanities And Social Science (IOSR-JHSS) Volume 21, Issue 5, Ver. 6 (May. 2016) PP 49-56 e-ISSN: 2279-0837, p-ISSN: 2279-0845.

Riding, A. \& Swift, C. (1990). Women business owners and terms of credit: Some empirical findings of the Canadian experience. Journal of Business Venturing, 5(5), 327-340.

Robb, A. and Wolken, J. D. (2002) Firm, Owner, and Financing Characteristics: Differences between Female- and MaleOwned Small Businesses. FEDS Working Paper No. 2002-18. Available at SSRN: https://ssrn.com/abstract=306800

Roy, I. (2016). “THE SOCIO-ECONOMIC CONTRIBUTION OF WOMEN ENTREPRENEURS IN BANGLADESH". International Journal of Economics, Commerce and Management, 4 (6), 1-12.
Schiffman, L. G., \& Kanuk, L. L. (2007). Consumer behavior, pearson education, inc. and dorling Kindersley publishing inc., p.172

Srinivas, H., "Borrower Evaluation in the Informal Credit Markets". GDRC Research Output E-110. Kobe, Japan: Global Development Research Center. Retrieved on Friday, 14 September 2018 (https://www.gdrc.org/icm/beval.html)

\section{Online Sources}

${ }^{1}$ https://en.wikipedia.org/wiki/Female_entrepreneurs

${ }^{2}$ https:/ /en.wikipedia.org/wiki/Mortgage_loan

http://www.worldometers.info/world-

population/bangladesh-population/

https://www.dhakatribune.com

$--0--$ 